\title{
Umami Taste of "Gyokuro" High Grade Green Tea
}

\author{
Hideki HoRIE, Tomomi UJIHARA and Katsunori KOHATA \\ National Institute of Vegetable and Tea Science \\ National Agricultural Research Organization
}

\section{Summary}

Gyokuro, high-grade green tea, contains a lot of amino acids. Umami is a very impor. tant taste for such high-grade teas. Amino acids and organic acids were analyzed in Gyokuro tea infusions. The model solution that imitates umami taste of the Gyokuro infusions was prepared according to the analytical data. It was estimated that glutamic acid, theanine and citric acid are important for umami taste of Gyokuro as results of the organoleptic omission tests from the model solution.

keywords: umami, green tea, citric acid, theanine, glutamic acid

\section{1 緒 言}

日本の緑茶にとってうま味は重要な要素で あり，うま味の強い茶が上級品とされる。な かでも覆い下栽培して生産される玉露におい ては, 特にうま味が重要である。

緑茶のうま味については, うま味の強い茶 に遊離アミノ酸が多く含まれることから，ア ミノ酸が関係するものとされてきたが，どの アミノ酸がうま味にとって重要であるか, 官 能検査を含めた詳細な検討は行われていな い。また有機酸であるコハク酸もうま味物質
とされ，さらにはクエン酸がグルタミン酸ナ トリウムによるうま味を強めるという報告も ある1。そこで, 本報においては, 通常飲用す る状態の玉露浸出液中の主要アミノ酸と有機 酸を分析し，これら茶成分のうま味への寄与 について官能検査し，どの成分が茶のうま味 に重要であるのか考察した。なお, 五基本味 という観点からは, うま味は甘味等とは独立 した味であるが，緑茶の評価においては，う ま味と甘味が必ずしもはっきりと区別されて いない場合も多いと考えられるため，本報に おいては，甘味も含めて考察した。

* T428-8501 静岡県榛原郡金谷町金谷2769 


\section{2 実 験 方 法}

3 種類の市販玉露について, 通常飲用する 条件で急須を用いて浸出した。浸出条件は, 茶葉 $10 \mathrm{~g}$ 五露用急須に入れ，これに $50^{\circ} \mathrm{C}$ の 蒸留水 $60 \mathrm{~m} l$ を加えた。急須に葢をして 2.5 分 後, 浸出液をビーカーに移した。浸出液にア ミノ酸分析の内部標準としてグリシルグリシ ンを添加し，水で25倍に希釈後，既報 ${ }^{2} に$ 基づ き高速液体クロマトグラフィーにより遊離ア ミノ酸を分析した。同じ試料について，キャ ピラリー電気泳動法により有機酸を分析し た3)。

上記の分析結果と個々のアミノ酸及び有機 酸の味の強さを考慮にいれながら, 玉露のう ま味を示すモデル液を調製した。モデル液組 成は表 2 に示した。このモデル液から，それ ぞれの成分を除去した場合, 味の変化が認識 できるか否かを 3 点比較法により官能検査し た。官能検查には，官能検查の訓練は受けて いないものの, 茶に関する知識は一般人より も深いものと考えられる野菜茶業研究所職 員, 臨時職員及び研修生を対象とし, 各項目
10人以上による試行の結果を有意差検定し た。

\section{3 実験結果および考察}

玉露を標準的な浸出方法で調製した場合の 浸出液中の主要アミノ酸及び有機酸の濃度を 表 1に示した。この分析結果と個々の成分の 味や闇値を考慮しつつ，玉露のうま味のモデ ル液として, 表 2 の組成の液を調製した。本 液には, カテキン類等苦渋味成分が添加され ておらず，香りもないため，玉露の味そのも のではないが, 玉露を想記させるだし汁様の うま味は有していた。

そこで，表 2 の組成液を玉露のうま味に関 するモデル液とし, 各々の成分を除去した液 との味の差を比較することにより, 各成分の 味への寄与を考察した。除去により明らかに 味が変化する成分は, 玉露のうま味への寄与 が大きいものと考えられる。その結果, グル タミン酸を除去した場合にはうま味が著しく 低下し，テアニンを除去した場合は甘味が， クエン酸を除去した場合は濃度感や飲用後も 口に残るような甘味が低下した。これらの成

表 1 玉露浸出液中の主要アミノ酸及び有機酸の濃度

\begin{tabular}{|c|c|c|c|c|c|c|c|c|}
\hline \multirow[b]{2}{*}{ 試料 } & \multicolumn{8}{|c|}{ 濃 度 $(\mathrm{mg} / \mathrm{l})$} \\
\hline & アスパテギン酸 & ダルタミン酸 & グルタミン & アルギニン & テアニン & シュウ酸 & リンゴ酸 & クエン酸 \\
\hline 1 & 739 & 562 & 880 & 809 & 2627 & 1064 & 417 & 602 \\
\hline 2 & 794 & 453 & 431 & 562 & 2516 & 1231 & 329 & 399 \\
\hline 3 & 774 & 396 & 460 & 438 & 2438 & 1141 & 222 & 400 \\
\hline
\end{tabular}

表 2 玉露のうま味モデル液組成と

モデ液から关れぞれの成分を除去した場合の味の变化

\begin{tabular}{|c|c|c|c|}
\hline \multirow[b]{2}{*}{ 成分 } & \multirow{2}{*}{$\begin{array}{c}\text { モデル液 } \\
\text { 濃度 }(\mathrm{mg} / \mathrm{l})\end{array}$} & \multicolumn{2}{|c|}{ 除去後の味変化 } \\
\hline & & 識別 & 味質変化 \\
\hline アスパラギン酸 & 800 & & . \\
\hline グルタミン酸 & 500 & $* *$ & うま味低下 \\
\hline アルギニン & 500 & & \\
\hline テアニン & 2500 & ** & 甘味低下 \\
\hline クエン酸 & 400 & * & 濃度感・甘味低下 \\
\hline
\end{tabular}

アスパラギン酸,グルタミン酸,クエン酸はナトリウム塩とした。

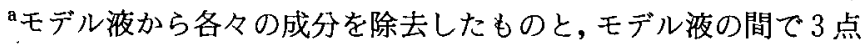
比較法により官能試験を行い, 正解率について有意差検定を行っ た。

**: $1 \%$ 水準, $*: 5 \%$ 水準で有意差あり。 
分は玉露のうま味や甘味への寄与が大きいも のと推定される。

テアニンについては，茶葉に含まれるアミ 酸の $50 \%$ 以上を占め，うま味・甘味を示す と記載されている。しかしながら，その闒值 が $1500 \mathrm{mg} / l^{4)}$ と高いため, 通常の方法でいれ た煎茶においては，味への寄与は大きくない ものと推定される。いっぽう，玉露では非常 に濃厚な浸出液を味わうため, テアニン濃度 が閾值とされる濃度よりも高くなり（表 1)， 甘味に寄与したものと推定される。ただし， モデル液で用いたテアニン濃度 $(2500 \mathrm{mg} / l)$ においては，グルタミン酸で感じられた強い 味の持続感は認められなかった。

クエン酸については, 食品の酸味成分とし て言及される場合が多く，酸味以外の味につ いては研究例は少なかった。原田ら”は,グル タミン酸ナトリウムのうま味をクエン酸が強 めることを最近報告したが，本研究結果は実 際の茶においても，クエン酸によるうま味増 強が認められることを示唆するものである。

いつ涩うアスパラギン酸については, 茶浸 出液中にテアニンに次いで多く含まれるアミ ノ酸であり，水溶液はうま味を示すと報告さ れているが, その閾值が $750 \mathrm{mg} /\left(\right.$ 程度 ${ }^{5)}$ と高い こともあり，除去による味の変化は認識でき なかった。アルギニンについては，一般には 苦味を示すアミノ酸と報告されているが，玉 露浸出液に含まれる程度の濃度では‘こく味’ やうま味に感じられた。アルギニンはズワイ ガニにおいてカニらしい味を示すのに必須と 報告され6)，玉露のうま味への寄与も大きい ものと期待されたが，モデル液からアルギニ ンを除去しても，味の変化としては識別でき なかった。

また，モデル液には含まれないものの，玉 露浸出液に比較的多く含まれるグルタミン及 びリンゴ酸をそれぞれ， $500 \mathrm{mg} / l, 300 \mathrm{mg} / l$ モデル液に添加したが，味の変化は識別でき なかった。

これらのことから，玉露のうま味にとって テアニン，グルタミン酸，クエン酸が重要と 考えられ，実際にこれら 3 成分のみを混合す
ることによってうま味の強い液が調製でき た。また，煎茶浸出液にこれら 3 成分を添加 したところ，玉露に類似する強いうま味を星 し，さらにアルギニンを添加することにより 玉露独特の風味が加わった。アルギニンとグ ルタミン酸の添加が茶の風味を改善したとい う報告》もあり，アルギニンの茶の味への寄 与についてはさらに検討する必要がある。

今回の試験においては，カテキン類等代表 的な苦渋味物質はモデル液に添加しなかっ た。それは, 玉露浸出液に含まれる $2000 \mathrm{mg} / l$ 以上のカテキン類を共存させると，その強い 苦渋味のために，うま味の評価が困難であっ たためである。著者らは玉露の渋味抑制には， 水溶性多糖類が寄与寸るものと考察してい

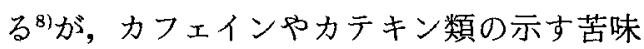
や渋味に対する抑制メカニズムを明らかにし たうえで，他の味関連成分や無機塩類も含め た系のなかで，アルギニン等各成分の茶の味 への影響について検討を続ける必要があ る。

$$
7
$$

\section{4 摘 要}

玉露浸出液中のアミノ酸及び有機酸を分析 し，これに基づき，玉露のうま味のモデル液 を調製した。このモデル液から，各成分を除 去したときの味の変化を官能検查した結果, グルタミン酸, テアニン, クエン酸が玉露の うま味にとって重要と考察された。

\section{5 謝辞}

官能検査に快く応じていただいた野菜茶業 研究所関係者に感謝します。

\section{6 引 用 文 献}

1）原田秀逸・金丸害一・笠原泰夫（2000： クエン酸とうま味物質の味賞相互作用に ついて.日本味と匂学会誌 7，621-622.

2 ) 後藤哲久・堀江秀樹・向井俊博（1993）: 緑茶中の主要アミノ酸のOPAによるプ レカラム誘導体化高速液体クロマトグラ フィーに上る分析。茶研報 No.77, 29-33. 
3）堀江秀樹・氏原ともみ・木幡勝則(2001）： 茶中に含まれる有機酸の含有量と品質と の関係。茶研報No.92（別）, 112-113.

4) 中川致之 (1991): 茶の味の成分. 村松敬 一郎編, 茶の科学, 朝倉書店, 東京, pp106-115.

5 ）吉田正昭・二宮恒彦 - 池田真吾 - 山口静 子・吉川知子・小原正美（1966）：アミノ 酸の呈味に関する研究 (第 1 報) 各種ア ミノ酸の刺激闘の測定. 農化 40 , 295-299.

6）福家真也(1999)：食品の味. 日本化学会
編, 味とにおいの分子認識, 学会出版セ ンター, 東京, pp.92-100.

7 ) 戸井文一・前田清一・佐々木 裕・鎌田 光雄・小池松平・赤堀 博 (1962)：添加 茶について (予報)。茶研報No.19, 96-99.

8 ）堀江秀樹・氏原ともみ・木幡勝則 (2000): 茶の味成分に関する新たな検討. 2 .玉露 の味についての考察.日本味と匂学会誌, $7,611-614$. 